\title{
Partisipasi Masyarakat Dalam Tradisi Penobatan Pemangku Adat Di Desa Air Teluh Kecamatan Kumun Debai Kota Sungai Penuh
}

\author{
Sandra Dwi Lanova, Isnarmi, Nurman \\ Program Studi Pendidikan Pancasila dan Kewarganegaraan \\ FIS Universitas Negeri Padang \\ Email: lanovadwisandra@gmail.com
}

\begin{abstract}
ABSTRAK
Penelitian ini bertujuan 1) mendeskripsikan partisipasi masyarakat dalam tradisi penobatan pemangku adat. 2) mendeskripsikan kendala dalam mengikuti tradisi penobatan pemangku adat. 3) mendeskripsikan upaya yang dilakukan pemangku adat dan masyarakat untuk meningkatkan partisipasi dalam tradisi penobatan pemangku adat di Desa Air Teluh Kecamatan Kumun Debai Kota Sungai Penuh.Penelitian ini menggunakan metode kualitatif deskriptif. Informan penelitian adalah tokoh adat, tokoh masyarakat, kepala desa serta masyarakat Desa Air Teluh.Teknik pengumpulan data dilakukan melalui observasi, wawancara, dan dokumentasi. Uji keabsahan data menggunakan triangulasi sumber. Teknik analisis data melalui tahapan mereduksi data, menyajikan data, dan menarik kesimpulan dari data yang diperoleh. Hasil penelitian menunjukkan bahwa partisipasi masyarakat dalam tradisi penobatan pemangku di Desa Air Teluh Kecamatan Kumun Debai Kota Sungai Penuh sudah ada namun belum sepenuhnya optimal. Bentuk partisipasi yang dilakukan masyarakat dalam bentuk sumbangan, keahlian serta tenaga. Kendala yang dihadapi masyarakat dalam tradisi penobatan pemangku adat yaitu masalah ketidak tarikan masyarakat, waktu yang terbatas, dan pekerjaan yang tidak bisa ditinggalkan. Upaya yang dilakukan pemangku adat dengan menarik minat masyarakat yaitu memberikan sosialisasi, melalui mobil keliling dan pengumuman dimesjid, serta pemangku adat memberikan peringatan kepada masyarakat yang tidak ikut.
\end{abstract}

Kata Kunci:Partisipasi, Masyarakat, Penobatan Pemangku Adat

\begin{abstract}
The aim of this study 1) describe peoples participation in coronation rite stockholder tradition. 2) describes obstacles in following coronation rite stockholder tradition. 3) describes the efforts undertaken by rite stockholder and peoples to increase participation in coronation rite stockholder tradition at Air Teluh village Kumun Debai districts Sungai Penuh city.This research uses descriptive qualitative method. The research informants are rite leaders, community leaders, village heads and also Air Teluh peoples.Technique of collecting data is done through observation, interview, and documentation. Test data validity using source triangulation. Data analysis techniques through the stages of reducing data, presenting data, and draw conclusions from the data obtained. The results showed that peoples participation in coronation rite stockholder at Air Teluh village Kumun
\end{abstract}


Debai districts Sungai Penuh city is already available but not fully optimal. Forms of community participation in the form of donations, skills and personnel. Constraints faced by society in coronation tradition of rite stockholder is problem of non-attraction of peoples, limited time, and work that can not be left behind. Efforts made by rite stockholder by attracting the public interest that is to provide socialization, through mobile cars and announcements in the mosque, as well as adat stakeholders provide a warning to people who do not participate.

Kata Kunci:Participation,Peoples ,Coronation rite stockholderv

\section{PENDAHULUAN}

Masyarakat merupakan sekumpulan orang yang, terdiri dari berbagai kalangan, baik golongan mampu ataupun golongan tak mampu, yang tinggal didalam satu wilayah dan telah memiliki hukum adat, norma-norma serta berbagai peraturan yang siap untuk ditaati. Masyarakat awalnya terbentuk dari sekumpulan orang saja. Misalnya sebuah keluarga yang dipimpin oleh kepala keluarga lalu kemudian berangsur-ansur dari sekeluarga membentuk RT dan RW hingga akhirnya membentuk sebuah dusun. Masyarakat berasal dari kata musyarak (arab), yang artinya bersama-sama, kemudian berubah menjadi masyarakat, yang artinya berkumpul bersama, hidup bersama dan saling berhubungan serta saling mempengaruhi, selanjutnya mendapat kesepakatan menjadi masyarakat Masyarakat (indonesia). ate (L Gillin dan J.P Gillin (dalam Abdul Syani, 2002 : 32) bahwa masyarakat adalah kelompok manusia yang terbesar dan mempunyai kebiasaan, tradisi, sikap dan perasaan persatuan yang sama.

Dalam suatu daerah partisipasi sangat diperlukan dikarenakan dengan adanya masyarakat, akan dapat memberikan manfaat bagi daerah tersebut. Sebagaimana yang dijelaskan Sastropoetro (1995:11) Partisipasi adalah keikut sertaan, peran serta atau keterlibatan yang berkaitan dengan keadaan lahiriahnya dan partisipasi juga menjelaskan tentang peran. masyarakat dalam mengambil bagiannya dalam suatu kegiatan, tidak hanya keterlibatannya secara fisik namun juga secara mental. Partisipasi berfungsi sebagai suatu kemitraan (patnership) dalam pembangunan. masyarakat dalam mengambil bagiannya dalam suatu kegiatan, tidak hanya keterlibatannya secara fisik namun juga secara mental. Partisipasi berfungsi sebagai suatu kemitraan (patnership) dalam pembangunan.

Partipasi masyarakat dapat tercipta apabila saling percaya dan saling pengertian antar anggota masyarakat dalam 
kehidupan sehari-hari. Pada saat sekarang ini banyak masyarakat yang telah melalaikan peran dan tanggung jawab mereka sebagai masyarakat disuatu daerah. Tradisi penobatan pemangku adat yang terdapat di Desa Air Teluh Kecamatan Kumun Debai Kota Sungai Penuh. Tradisi penobatan pemangku adat adalah pengangkatan yang dipilih oleh anak betina, anak betina merupakan anak dari tokoh adat yang telah memiliki jabatan ataupun gelar adat, jabatannya seumur hidup atau selama pemangku Adat itu sendiri masih sanggup untuk memegang amanah yang di berikan kepadanya dan akan digantikan pemilihannya ketika pemangku adat meninggal dunia yang digantikan oleh keponakannya.

$$
\text { Tradisi penobatan }
$$

pemangku adat bertujuan untuk mendapatkan gelar dan tugas yang sama dengan pemangku adat sebelumnya. Dalam penobatan pemangku adat didaerah Desa Air Teluh Kecamatan Kumun Debai Kota Sungai Penuh diperlukan partisipasi masyarakat dikarenakan yang akan memilih pemangku adat adalah masyarakat itu sendiri. Namun pada kenyataannya partisipasi masyarakat dalam pemilihan pemangku adat belum optimal, padahal masyarakat wajib untuk memilih dan mengikuti tradisi penobatan pemangku adat tersebut. Begitu juga dengan kesadaran masyarakat terhadap nilai-nilai budaya dalam penobatan pemangku adat masih kurang. Dengan kurangnya kesadaran masyarakat terhadap nilai-nilai budaya tersebut berdampak pada peran ninik mamak dalam membimbing kemenakannya dalam mengikuti tradisi penobatan pemangku adat tersebut.

Sebagaimana observasi awal yang telah peneliti lakukan dengan bapak Syafrizal selaku tokoh adat di Desa Air Teluh Kecamatan Kumun Debai Kota Sungai Penuh "kebanyakan masyarakat yang berpartisipasi dalam proses pemangku adat masih kurang, padahal pelaksanaan tradisi penobatan pemangku adat diwaktu hari libur" (Wawancara pada tanggal 25 juli 2017 pukul 14.00 wib). Kedua dengan Bapak Amin selaku masyarakat di Desa Air Teluh Kecamatan Kumun Debai Kota Sungai Penuh "dikarenakan pekerjaan yang tidak bisa ditinggalkan, sehingga Bapak Amin sendiri tidak berpartisipasi dalam pelaksanaan tradisi penobatan pemangku adat" (wawancara pada tanggal 25 juli 2017 pukul $16.00 \mathrm{wib})$.

Berdasarkan paparan permasalahan diatas jelas bahwa masih ada atau masih banyak permasalahan dikalangan masyarakat untuk dapat mengikuti tradisi penobatan pemangku adat. Hal ini sangat penting dikarenakan menyangkut keamanan dari masyarakat kota sungai penuh. Jika dilakasanakan 
Partisipasi Masyarakat dalam..

dengan baik akan dapat memberikan kemajuan bagi daerah Desa Air Teluh Kecamatan Kumun Debai Kota Sungai Penuh. Berdasarkan permasalahan diatas penulis ingin meneliti bagaimana "Partispasi Masyarakat dalam Tradisi Penobatan Pemangku Adat di Desa Air Teluh Kecamatan Kumun Debai Kota Sungai Penuh.

\section{METODE PENELITIAN}

Penelitian ini bersifat deskriptif dengan menggunakan pendekatan kualitatif. Penentuan informan menggunakan teknik purposive sampling. informan yaitu tokohmasyarakat, tokohadat, kepala desa danmasyarakat Desa Air Teluh. Teknik yang digunakan adalah observasi, wawancaradanstudidokumentasi

. Setelah data terkumpul, diolah dengan teknik analisis data yaitu reduksi data, penyajian data danpenarikankesimpulan.

\section{HASIL DAN PEMBAHASAN}

1. Partisipasi masyarakat dalam tradisi penobatan pemangku adat di Desa Air Teluh Kecamatan Kumun Debai Kota Sungai Penuh

Berdasarkan penelitian yang dilakukan peneliti di Desa Air Teluh Kecamatan Kumun Debai Kota Sungai Penuh didapatilah bahwa bentuk partisipasi yang dilakukan masyarakat dalam bentuk sumbangan, keahlian dan tenaga. Partisipasi masyarakat dalam tradisi penobatan pemangku adat di Desa Air Teluh Kecamatan Kumun Debai Kota Sungai Penuh cukup baik namun belum sepenuhnya optimal. Dalam tradisi penobatan pemangku adat ada enam jenis-jenis partisipasi menurut Santoso Sastropoetro (1988 : 16) pada hasil penelitian ditemukan tiga jenis yaitu :

\section{Tenaga}

Bentuk partisipasi yang dilakukan masyarakat yaitu mengantarkan undangan kerumah tokoh adat, tokoh masyarakat dan wali kota, mencatat perlengkapan, mendirikan pentas dan mengias pentas yang bertanggung jawab seksi perlengkapan) dan menyiap makanan yang bertanggung jawab seksi konsumsi.

2. Keahlian

Partisipasi masyarakat dalam bentuk keterampilan keahlian dalam tarian, pencak silat dan managemen acara masih cukup baik namun belum optimal dilaksanakan, dikarenakan kesibukkan dari masyarakat itu sendiri.

3. Uang

Partisipasi masyarakat dalam bentuk iuran lebih dominan dilakukan. Dengan partisipasi uang masyarakat yang mempunyai keluarganya jauh juga dapat berpartisipasi. Iuran berupa masyarakat biasa, pensiun dan pegawai Rp.100.000,00 maupun anggota keluarga pemangku adat. Sehingga dapat mendorong 
pelaksanaan tradisi penobatan pemangku adat Desa Air Teluh.

Tradisi penobatan pemangku adat diperlukan partisipasi masyarakat, menurut Mikkelsen (1999 : 64) ada enam pada hasil penelitian ditemukan dua partisipasi yaitu :

a. Partisipasi adalah kontribusi sukarela dari masyarkat kepada proyek tanpa ikut serta dalam pengambilan keputusan.

Partisipasi masyarakat dalam tradisi penobatan pemangku adat terdapat masyarakat umum memberikan sumbangan(uang) secara suka rela tanpa ada ditetapkan untuk mendorong pelaksanaan penobatan pemangku adat.

b. Partisipasi adalah keterlibatan masyarakat dalam pembangunan diri, kehidupan dan lingkungan mereka.

Partisipasi masyarakat dalam bentuk keahlian atau keterampilan, masyarakat dilatih untuk menampilkan hasil yang maksimal dalam pelaksanaan penobatan pemangku adat.

Sifat dan ciri partisipasi masyarakat dalam tradisi penobatan pemangku adat menurut Santoso Sastropoetro (1988 : 23 ) ada empat dalam hasil penelitian menunjukkan satu yaitu :Partisipasi haruslah bersifat sukarela yaitu masyarakat dalam pelaksanaan penobatan pemangku adat memberikan sumbangan tidak di tetapkan dan masyarakat memiliki keluarga jauh juga dapat berpartisipasi dalam bentuk sumbangan. Partisipasi masyarakat Desa Air Teluh merupakan keikutsertaan masyarakat didalam kelompok sosial untuk kegiatan dalam pelaksanaan penobatan pemangku adat, diluar pekerjaannya sendiridalam kamus sosiolog (Theoderseon, 1969) yaitu mengambil bagian melalui keahlian atau keterampilan yang dimilikinya kepada anggota masyarakat yang lain yang membutuhkan untuk meningkatkan kesejahteraan sosialnya. Keterampilan yang terlihat dan disalurkan tersebut adalah kemampuan dalam seni tari dan pencak silat. Masyarakat melatih sebelum kegiatan tradisi penobatan pemangku adat dimulai. Walaupun dari segi pelaksanaannya, masyarakat belum sepenuhnya optimal dalam memberikan pelatihan bagi masyarakat di karenakan kesibukkan dari masyarakat itu sendiri serta dalam segi latihanya tidakberkesinambungan.

Pentingnya partisipasi masyarakat Desa Air Teluh Menurut Adisasmita (2006 : 38) adalah keterlibatan anggota masyarakat dalam pembangunan desa, meliputi kegiatan dalam perencanaan dan pelaksanaan dalam tradisi 
penobatan pemangku adat untuk membangun partisipasi masyarakat. Partisipasi masyarakat dalam bentuk tenaga sangat dibutuhkan, karena yang berpartisipasi masyarakat yang menjadi panitia pelaksana. Adapun bentuk partisipasinya yaitu mengantarkan undangan kepada tokoh adat, tokoh masyarakat dan wali kota. Masyarakat yang telah dibentuk kepanitiannya dalam mempersiapkan managemen acara, susunan acara pelaksanaan tradisi penobatan pemangku adat seperti mencatat perlengkapan, mendirikan pentas sekaligus menghiasi pentas, sebelum terlaksananya tradisi penobatan. Hal ini disesuaikan.

Bentuk

-bentuk

pasrtisipasi yang dilakukan masyarakat Desa Air Teluh menurut Santoso Sastropoetro (1988 : 16) ada enam, hasil penelitian menunjukkan dua bentuk pasrtisipasi yaitu dari :

1. Sumbangan spontan berupa uang dan barang.

Bentuk partisipasi sumbangan yaitu masyarakat yang tidak bisa hadir dalam pelaksanaan penobatan pemangku adat menggantikan dengan sumbangan(uang).

2. Sumbangan dalam bentuk kerja, yang biasanya dilakukan oleh tenaga ahli setempat.

Bentuk partisipasi keahlian yaitu menyalurkan keterampilan yang dimilinya untuk pelaksanaan penobatan pemangku adat, dan bentuk partisipasi tenaga yaitu menyumbangkan tenaga dengan bergotong royong secara bersama-sama .

2) Kendala masyarakat dalam mengikuti tradisi penobatan pemangku adat di Desa Air Teluh Kecamatan Kumun Debai Kota Sungai Penuh

Dalam pelaksanaan tradisi penobatan pemangku adat terdapat kendala masyarakat dalam mengikuti pelaksanaan tradisi penobatan pemangku adat. Kendala tersebut tercipta karena perubahan yang dilakukan oleh masyarakat. Faktor-faktor yang mempengaruhi partisipasi masyarakat Desa Air Teluh Menurut Santoso Sastropoetro (1988 : 22 ) adalahTidak terdapatnya kesempatan untuk berpartisipasi dalam berbagai program pembangunan yaitu masalah waktu yang tidak memadai, kurangnya ketertarikan masyarakat mengenai adat istiadat dan ada pekerjaan yang tidak bisa ditinggalkan.

3) Upaya yang dilakukan pemangku adat dan masyarakat untuk meningkatkan partisipasi dalam tradisi penobatan pemangku adat di Desa Air 
Teluh Kecamatan Kumun Debai Kota Sungai Penuh

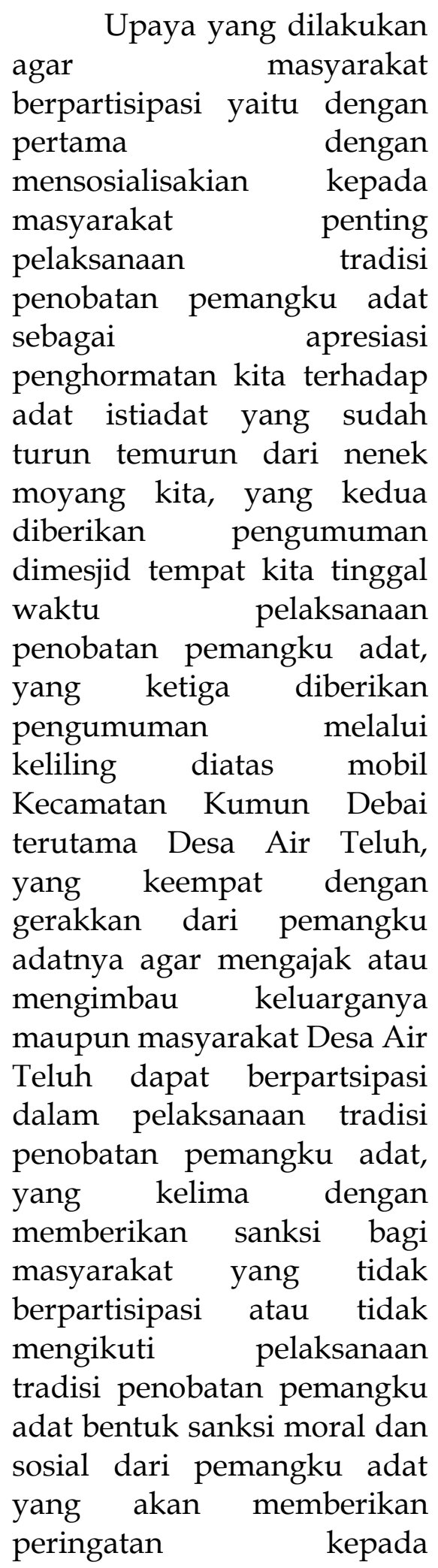

masyarakat yang tidak berpartisipasi.

Upaya yang dilakukan untuk melakukan pelestarian nilai budaya pada saat pelaksanaan penobatan pemangku adat yaitu dengan beberapa upaya yang dilakukan agar masyarakat mau berpartisipasi. Begitu juga yang dilakukan oleh pemangku adat serta masyarakat mereka melakukan kontrol atau pengawasan kepada masyarakat. Dengan membentuk panitia pelaksana menjalankan tugasnya masing-masing sehingga tetap ada dukungan dari masyarakat dalam pelaksanaan tradisi penobatan pemangku adat.

\section{KESIMPULAN}

Berdasarkan uraian hasil penelitian yang telah peneliti kemukakan tentang partisipasi masyarakat dalam tradisi penobatan pemangku adat di Desa Air Teluh Kecamatan Kumun Debai Kota Sungai Penuh dapat diketahui bahwa partispasi yang dilakukan masyarakat cukup baik namun belum sepenuhnya optimal dikarenakan kesibukan dari masyarakat itu sendiri.Partisipasi masyarakat yang lebih dominan dilakukan dalam bentuk sumbangan. Selain itu partisipasi yang 
dilakukan masyarakat yaitu dalam bentuk keahlian dan tenaga.

Kurangnya partisipasi masyarakat memunculkan kendala dalam pelaksanaan tradisi penobatan pemangku adat. Kendala waktu yang tidak terbatas, ada beberapa masyarakat yang tidak tertarik pada pelaksanaan penobatan pemangku adat dan masalah pekerjaan yang tidak bisa ditinggalkan. Meskipun pemangku adat telah melakukan berbagai upaya untuk menarik minat masyarakat seperti melakukan sosialisai dimasyarakat, melalui mobil keliling dan pengumuman mesjid, kemudian pemangku adat memberi sanksi kepada masyarakat yang tidak ikut.

\section{DAFTAR PUSTAKA}

Abdulsyani. 2012. Sosiologi Skematika, Teori dan Terapan .Jakarta : Bumi Aksara

Aprilia Theresia dkk. 2014.Pembangunan Berbasis Masyarakat. Bandung : Alfabeta

Conyers, Diana. 1991. Perencanaan Sosial di Dunia ketiga. Yogyakarta: UGM Press

Elly. M. Setiadi.dkk. 2013. Pengantar Sosiologi Pemahaman Fakta dan Gejala Permasalahan Sosial: Teori,Aplikasi dan Pemecahannya. Jakarta:Kencana

Hamid Darmadi. 2014. Metode Penelitian Pendidikan dan Sosial. Bandung:Alfabeta

Isbandi Russskminto Adi. 2007. Perencanaan Partisipatoris Berbasis Aset Komunitas: dari Pemikiran Menuju Penerapan. Depok: FISIP UI Press Lexy J. Moleong. 2012. MetodePenelitian Kualitatif. Jakarta:Gramedia. M. Jazuli. 2014. Sosiologi Seni Edisi 2 Pengantar dan Model Studi Seni. Yogyakarta : Graha Ilmu

Mikkelsen, Britha. 2001. Metode Penelitian Partisipatoris dan Upaya upaya Pemberdayaan: sebuah buku pegangan bagi para praktisi lapangan. Jakarta: Yayasan Obor Indonesia

Ndaraha, Taliziduhu. 1999. Pembangunan Masyarakat Mempersiapkan Masyarakat Tinggal Landas. Jakarta : Rhineka Cipta

Santoso, Satropoetro. 1988. Partisipasi, Komunikasi, Persuasi dan Disiplin Ilmu dalam Pembangunan. Bandung: Alfabeta.

Sugiyono. 2014. Penelitian Kualitatif Edisi Revisi. Bandung : Alfa Beta 